\title{
STUDIES
}

Article received on September $9^{\text {th }} 2017$ Article accepted on November $13^{\text {th }} 2017$

UDC: 78.01

$78: 32 " 20 "$

\author{
Jeff R. Warren* \\ Quest University in Squamish \\ British Columbia, Canada
}

\section{MUSIC ETHICS POLITICS}

\begin{abstract}
In the twenty-teens, music has been wrapped up in politics and ethics in several prominent events, including violent attacks at the Bataclan theatre in Paris and the Pulse Nightclub in Orlando, and the profiling of musical listening habits in the French governments "stop jihadism" campaign. Significant scholarship exists on music and politics, and interest in music and ethical philosophy is growing. More work, however, is needed in theorizing the connections between music, ethics, and politics. In 1951, Heidegger's essay "Building Dwelling Thinking" lists the words in the title without punctuation in an attempt to show how these three terms are intertwined even though they are often considered separate. While these words and concepts are not interchangeable, each relies upon or invokes the other. My title structurally mirrors Heidegger's, and my aim here is to elucidate how music is intertwined with ethics and politics.
\end{abstract}

Keywords: music, philosophy, ethics, politics, phenomenology, relational musicology

* Author contact information: jeff.warren@questu.ca 


\section{Music Ethics Politics}

In the twenty-teens, music has been wrapped up in politics and ethics in several violent public events, revealing how music - whether it wants to or not - is intertwined with ethics and politics.

In January 2015, the Charlie Hebdo office in Paris was attacked by an Islamic extremist group apparently reacting to the depictions of Mohammed in their satirical publication. Shortly after, the French government launched an almost half billion dollar anti-terrorism campaign, which featured a "stop jihadism" website that instructs its citizens how to identify budding Islamic extremists. ${ }^{1} \mathrm{~A}$ prominent infographic on the website included a checklist of suspicious activities citizens could use to profile those around them. The list included expected items such as frequenting radical websites, but the central image on the infographic was "they stop listening to music" for the reason that "it distracts them from their mission". 2 The list - and the music item in particular - was quickly mocked by several media outlets with some form of the argument that listening to music is really just a matter of private taste. ${ }^{3}$ However, it could be argued that the French government has a significant grasp on the political nature of music. Whereas the mocking journalists assume that music is a matter of individual taste, a private consumption of a neutral commodity that has no relation to politics, the French government asserts that participation in music marks belonging to a larger social system. If music "distracts them from their mission", then are the rest of the citizenry without a mission? Or is listening to music part of the mission of the good modern citizen loyal to the nation, democracy, and capitalism?

In November 2015, Paris was once again the site of horrific attacks. This time, a popular music concert was one site of the deadliest attack in France since WWII. ${ }^{4}$ At the Bataclan concert venue on Boulevard Voltaire, at least 89 people were killed at a concert where the American rock group Eagles of Death Metal were playing to a crowd of approximately 1,500 people. On 11 June 2016, the deadliest mass shooting by a single gunman in American history took place on "Latin night" at the Pulse gay night club in Orlando. ${ }^{5}$ On 22 May 2017, twen-

${ }^{1}$ Ishaan Tharoor, "Are You a Jihadist? France's Checklist Includes Questions About Diet, Wardrobe and Not Listening to Music", Washington Post, 30 January 2015.

${ }^{2}$ http://www.stop-djihadisme.gouv.fr/decrypter.html

${ }^{3}$ For example, see Ishaan Thaoor, „Are You a Jihadist? France's Checklist Includes Questions About Diet, Wardrobe and Not Listening to Music", op. cit.

${ }^{4}$ Cf. Tracy McVeigh and Emma Graham-Harrison, "Parisians throw open doors in wake of attacks, but Muslims fear repercussions", The Guardian, 14 November 2015.

5 Ethnomusicology Review's online "Sounding Board" published a set of responses to this event (http://ethnomusicologyreview.ucla.edu/sounding-board/special-issue). 
ty two people were killed in a suicide bombing at an Ariana Grande concert in Manchester. In these tragic events, music was central to the gathering. The locations of the attack might be attributed to chance, but I believe it reveals something important about music and politics. Music creates gatherings of people. Music creates social spaces within larger political spheres. Gathering with others to make music, dance to music, or listen to music is part of a larger political realm, whether we actually notice it or not, and becomes even more complex when considering meanings attributed to the musical sounds. ${ }^{6}$
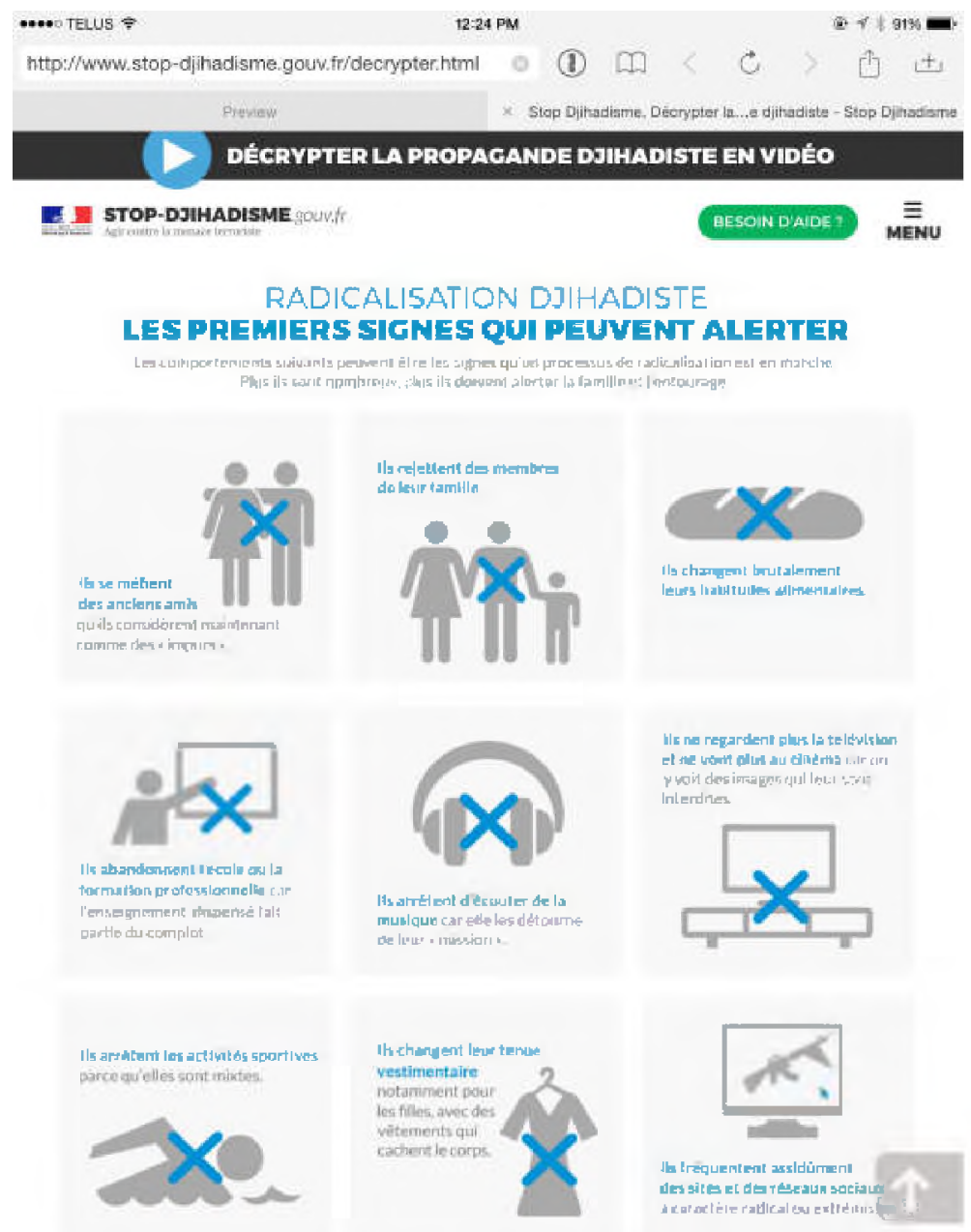

${ }^{6}$ A wider discussion about musical meaning can be found in Chapter 2 of Jeff R. Warren, Music and Ethical Responsibility, Cambridge, Cambridge University Press, 2014. 
These recent events provide examples of how music is often present in events of significant import. Yet music is also part of less public and less violent events that also involve ethics and politics. Too often, however, music's relation with ethics and politics is not considered beyond a surface level. It is worth taking some effort to begin to sketch out connections between ethical philosophy, politics, and music to assist our considerations about how to respond not only to horrific events like these, but to everyday events.

In 1951, Heidegger's essay "Building Dwelling Thinking" lists the words in the title without punctuation in an attempt to show how these three terms are intertwined even though they are often considered separate. ${ }^{7} \mathrm{He}$ argues that these words and concepts are not interchangeable, and each relies upon and invokes the other. My title structurally mirrors Heidegger's, and my aim here is to begin to open up how music is intertwined with ethics and politics. In earlier work I argued that musical experience creates encounters with others, and that these encounters lead to ethical responsibilities. ${ }^{8}$ Here, I extend this argument to politics, drawing upon arguments from musicology, ethical philosophy, and phenomenology. Relations between music, ethics, and politics cannot be completely enumerated, but include: music disclosing political possibilities, music performing ethical ideas about self and other that influences politics, and ethical and political norms guiding music making. My hope is that considering the intertwinement of music, ethics, and politics might provide us - as citizens and those working with music - with ways of responding to the events that surround us.

Heidegger's questionable primary method of building evidence for his argument of how these building, dwelling, and thinking are intertwined is etymology; that is, uncovering the linkages of the terms through root meanings of the words. This method is how, for example, he makes the argument that not every building is a dwelling, but even though these two words are distinguishable, they need to be thought of together. While I do not subscribe to this method as the primary means of making my argument, it is interesting that the etymologies of the words under investigation here open up many of the questions that echo current performative uses of the words. The word "politics" has related to terms involving the state (polis), organizational policies (politia), and citizens (polites). ${ }^{9}$ Theodore Adorno, at the beginning his 1963 lectures on the problems of moral philosophy, establishes that one of the initial problems we must face

7 Martin Heidegger, "Building Dwelling Thinking”, Poetry, Language, Thought, New York, Harper Colophon Books, 1971.

8 Warren 2014.

9 Cf. T.F. Hoad, The Concise Oxford Dictionary of English Etymology, Oxford, Oxford University Press, 1996, 360. 
stems from the usages of the terms morality and ethics. Morality's etymology is in the Latin mores or social custom, whereas ethics is derived from Greek ethos, which roughly translates as "the way you are, the way you are made". ${ }^{10}$ Adorno criticizes both the potential relativism of an ethic of being yourself as well as the authority of custom as he develops his argument. Modern uses of these terms from Kant to Foucault to George W. Bush blur and blend the etymological roots, with arguments ranging from the idea that personal preference or identity should lead to social norms to the ideas that norms established by reason or gods or decree should be adopted in the personal dispositions and politics of citizens. In both politics and ethics one of the keys is investigating the question between the individual and the collective, and while this question has not been answered, the fact that it remains a question shows how politics and ethics remain intertwined. Music's etymology as a sensory art rooted in inspiration from the goddesses or muses seems - at least on the surface - removed from ethics and politics. Here we run against a limit of Heidegger's etymological method. A contorted argument could be made from the word's root either about the links to or separation from ethics and politics. Instead of making such an attempt, in what follows I base my argument on the intertwinement of music with ethics and politics on the performative usage of music rather than etymology. ${ }^{11}$

Later in his paper, Heidegger develops the idea of the "fourfold", four elements that rely upon or invoke the others. He argues that "When we say earth, we are already thinking of the other three along with it, but we give no thought to the simple oneness of the four". ${ }^{12}$ I have no desire to involve myself here in an argument about the ontology of the fourfold, but what might be taken from this argument is the idea - developing from Hegel to Heidegger and expanded upon by Derrida and others - that things and ideas are not atomistic and involve unspoken relations with other things and ideas. In relation to my argument, politics involves ethics and music, ethics involves politics and music, and music involves politics and ethics. Following Heidegger's etymological process revealed some of the relationships of these three. But etymology has limits, and in what follows, I examine other evidence and arguments in the hopes of beginning a sketch of how music, ethics, and politics relate.

With so much written in and around the topics of music, ethics, and politics, one could reasonably ask what one article could hope to contribute. To be clear,

10 Theodor W. Adorno, Problems of Moral Philosophy, Stanford, CA, Stanford University Press, 2001, 9, 10.

11 In an emphasis on music as experienced, my aim is for my argument to resonate with phenomenology, even if particular phenomenological descriptions are not undertaken.

12 Martin Heidegger, op. cit., 147. 
my aim is modest, and I make no attempt to be comprehensive. In this short space, I aim for a general relation of music, ethics, and politics and surely leave many questions unanswered and detailed textual readings unfinished. Articles that make a modest but definite contribution are key to the discipline, but here I make the sketch of ideas that hopes to continue larger dialogues taking place in several academic realms. I aim to make both a negative argument and a positive argument, showing approaches to these questions that are problematic and trying to open up what might be profitable. I begin with an examination of how each of these terms relates to the other before returning to discussing what this sketch might lead to.

\section{Ethics and Politics}

In the preface to Totality and Infinity, philosopher Emmanuel Lévinas claims that "politics is opposed to morality, as philosophy is to naïveté". ${ }^{13} \mathrm{He}$ cites war as a political act wherein "individuals are reduced to being bearers of forces that command them" ${ }^{14}$ The result is that "the state of war suspends morality". ${ }^{15}$ By prefacing his first magnum opus with the claim that politics reduces individuals and suspends morality places a seemingly unachievable chasm between ethics and politics. For Lévinas, ethical responsibility is mine for the other person, and political forces get in the way of or cover over responsibilities. In Levinasian terms, "totality reduces the ethical to the political". ${ }^{16}$ However, in the preface of the German translation of the same text, Lévinas writes that in his book justice serves as a synonym for the ethical. ${ }^{17}$ Simplistically put, Lévinas's notion of justice is what happens when we need to respond to more than one person. Of course, this is the situation of everyday life, and thus the situation of ethical life. However, the tension remains: ethics as justice includes the world of politics, but politics opposes ethics. In other words, "ethics leads back to politics, to the demand for a just polity", ${ }^{18}$ and yet just politics remains an unfulfilled promise. Rather than writing off Lévinas on account of contradiction or attempting to smooth over the apparent contradiction, it might be useful to embrace this contradiction as core to

\footnotetext{
${ }^{13}$ Emmanuel Lévinas, Totality and Infinity, Pittsburgh, Pennsylvania, Duquesne University Press, 1969, 21.

14 Ibid.

15 Ibid.

16 Simon Critchley, "Introduction", The Cambridge Companion to Levinas, Bernasconi, R. and S. Critchley (Eds.), Cambridge, Cambridge University Press, 2002, 24.

17 Gary Gutting, Thinking the Impossible: French Philosophy Since 1960, Oxford, Oxford University Press, 2011, 135.

18 Simon Critchley, op. cit., 24.
} 
the links between ethics and politics. Adorno argues problems where we cannot eliminate contradiction are the ones we need to continue facing. ${ }^{19}$

If we admit this contradiction, then there is no possibility of ethics being absorbed into politics. There is no possibility of covering over this tension with some sort of unifying 'just war' theory. Politics will always fail to respond ethically to all others, and ethics will always fail when it aims to move from responding to the other to creating a larger system. But each informs the other, and - even if it isn't possible - it is still worthwhile to work towards an ethics that can be politically fulfilled and a politics rooted in ethics. Since the late 1960s, the so-called 'ethical turn' (which Lévinas's work influenced) has lead to increased debates about the relation of ethics and politics in areas as diverse as business ethics and identity politics. ${ }^{20}$ Philosophers and politicians continue to wrestle with how politics and ethics relate, but should also not be surprised when they do not.

In short, while politics and ethics surely are not synonymous, they cannot be thought of separately. A significant literature exists on topics of ethics and politics and this discussion could be far extended, but the main point here is that they do relate. The problem I turn to now is how music relates to ethics and politics.

\section{Music and Ethics}

Over the past number of years, several movements in musicology (and related disciplines) have grown discontented with positivistic and formalistic musicological approaches that often assume musical experience is sealed off from relationships with and responsibilities to others. In other words, these views claim music is separate from ethics (and that at least some music is also separate from or 'above' politics). Challenges to these problems sometimes fall into opposite but similar errors that either take an individual's experience as representative of all experience, or take the solipsistic position that the most we can do is explain our own experiences.

One of the ways scholars in several disciplines have resisted these pitfalls is through an emphasis on the relationality of music; in other words, the relations within and surrounding musical usage. Work in this area has been far from unified, but includes approaches from ethnomusicology, cross-cultural musicology, performance studies, and the phenomenology of music. While scholars

\footnotetext{
19 Cf. Theodor W. Adorno, op. cit., 9.

${ }^{20}$ For more on the 'ethical turn', see Gary Gutting, op. cit., and Julian Bourg, From Revolution to Ethics: May 1968 and Contemporary French Thought, Montreal, McGill-Queen's University Press, 2007.
} 
with overlapping interests often find and read the work of others, their varying disciplinary affiliations often mean that they do not cross paths regularly at disciplinary events such as academic conferences. Attempts to draw together these disparate methods of examining music and human relations has begun under the banner of 'relational musicology'. Notable here is work by Nicholas Cook and Georgina Born. Born argues that relational musicology responds to the problematic assumption that the social is outside of the "music itself". ${ }^{21}$ Born is critical of many musicological approaches, and seems to identify the way forward as the adoption of approaches influenced by Foucault and others. While such study is surely profitable (and is already taking place), such approaches do not account for all elements of relationality. Cook also identifies the prevailing problem with approaches to music that begin with an assumption of what music is, and as a solution seems to cast the net of what counts as relational wider in his inclusion of the personal, social, cultural, and intercultural. ${ }^{22}$

A forerunner of the term 'relational musicology' is 'relational aesthetics', the idea coming out of France in the 1990s that makes claims that "art is the state of encounter" and aims to transform the practice of art making to transforming social relations. ${ }^{23}$ Theories of relationality, however, have a far longer history. As current concepts of relationality are grounded within larger theories of the place of human beings in the world, I'll very briefly trace some of these ideas within modern Western thought.

Descartes attempted to ground knowledge outside of the relation to our experience. Immanuel Kant saw the difficulty with his and attempted to ground objectivity in subjectivity. ${ }^{24}$ Both positions assume that the main question about relationality is how a subject comes into relation with an object. Hegel criticizes the presumption that the starting point is an isolated individual accessing an external world. Instead, he argues that anything we speak or know about is something we are already in relation with. He uses the metaphor of swimming: you cannot swim without being in the water. In the same manner, we are already in relation with anything we encounter. ${ }^{25}$

${ }^{21}$ Cf. Georgina Born, "For a Relational Musicology: Music and Interdisciplinarity, Beyond the Practice Turn", Royal Musicological Association Vol. 135, No. 2, 2010, 208.

22 Cf. Nicholas Cook, "Anatomy of the Encounter: Intercultural Analysis as Relational Musicology", in: Stan Hawkins (Ed.), Critical Musicological Reflections: Essays in Honour of Derek B. Scott, Farnham, Ashgate, 2012.

23 Nicolas Bourriaud, Relational Aesthetics, s.1., Les presses du reel, 1998, 18.

24 Cf. Andrew Bowie, German Philosophy: A Very Short Introduction, Oxford, Oxford University Press, 2010, 10.

25 Ibid., 47. 
Moving into the $20^{\text {th }}$ century, phenomenology continued examining relationality through "an intense examination of experience in its multifaceted, complex, and essential forms" ${ }^{26}$ Heidegger, for example, argues that experience is much more complex than the subject/object relations of Descartes through showing how the everyday world contains others. Part of his argument in Being and Time examines how on the one hand our relations with others shape our relations with the world, and on the other hand, how our relations with the world shape our relations with others. ${ }^{27}$ While Heidegger extends the description of relationality within human experience, his penchant for overarching concepts sees others as a mass and fails to take into account relations with individual others.

It is with Maurice Merleau-Ponty and Emmanuel Lévinas - each of whom played an important role in the influence of phenomenology in France and beyond - that the relationality of the individual other is more closely examined. Merleau-Ponty helpfully illuminates the intertwined elements of relationality in his claim that "thought is a relationship with oneself and with the world as well as a relationship with the other; hence it is established in the three dimensions at the same time". ${ }^{28}$ In short, relationality leads us to consider relations with other living and non-living things, questioning how we encounter them, what we know about them and about how we are to respond to them. Responding to others is the core of ethics, and determining how to respond is the core of ethical reasoning. ${ }^{29}$

To put this argument crudely, people bump into other people in the world, and have to make decisions about how to respond. Ethics ensues. Music bumps into people, and sometimes is the medium through which people bump into others. All of these encounters that music is a part of ('bumping into' in my crude terminology) are what those who call for a relational musicology (among others) think have been overlooked in musicology and should instead be central concerns. And of course all of these 'bumpings' are far more complex than the simplistic terms I've been using, as they involve individuals, culture, power, and wider political issues.

26 Don Idhe, Listening and Voice: Phenomenologies of Sound, $2^{\text {nd }}$ Edition, Albany, SUNY, $2007,17$.

27 Cf. Martin Heidegger, Being and Time: A Translation of Sein Und Zeit, New York, SUNY, 1996.

${ }^{28}$ Maurice Merleau-Ponty, "The Intertwining - the Chiasm", in: Clive Cazeaux (Ed.), The Continental Aesthetics Reader, New York, Routledge, 2000, 173.

${ }^{29}$ In my book Music and Ethical Responsibility, I argue that "musical experience involves encounters with others, and ethical responsibilities arise from these encounters". Jeff R. Warren, op. cit., 1 .. 
Additionally, it is important to remember that sometimes the sounds we call 'music' bump into things that are not people. The philosophical views that have gone by the names 'object oriented ontology' and 'speculative realism' have reminded us that most of our scholarly efforts concentrate on how people relate to the things around us. ${ }^{30}$ Things, however, bump into lots of other things that are not human beings. Ian Bogost's book - subtitled "what it's like to be a thing" 31 - attempts to consider how we can speculate about how non-human things encounter the world. While I will not attempt to speculate on what it might be like for music to bump into other things in the world here, this line of philosophy serves as an important reminder that as much as we may wish to reduce music to only human relations, music is also separate from human beings. Considered this way, music can be outside of ethics, or at least ethics conceived of as human responsibilities. Music might have a much more interesting existence than we give it credit for. But the main point I am aiming at here is that when music is part of human experience it is intertwined with ethics.

If music and ethics are bound up together, it is also worth considering the role music might have in philosophical ethics; that is, the people who think and write about ethics. To take one example of this line of thinking, François Noudelmann speculates about the role that playing the piano had on the development of the philosophy of Sartre, Nietzsche, and Barthes ${ }^{32}$ Noudelmann's argument is an interesting one, for surely what is written about in professional life is influenced by personal experiences, and experiences of music can shape ways of thinking. ${ }^{33}$ Philosopher Andrew Bowie, in his book Music, Philosophy, and Modernity, claims that saxophone playing "proved vital to the crystallisation of the book's ideas", and suggests that "one of the best philosophical things one can do is to listen to and play more good music" ${ }^{34}$ Even when absent in written products, musical experience might play an important role in ethical philosophy.

\footnotetext{
${ }^{30}$ An influential version of this criticism can be found in Quentin Meillassoux, After Finitude: An Essay on the Necessity of Contingency, London, Continuum, 2009.

31 Ian Bogost, Alien Phenomenology, or What it's Like to be a Thing, Ann Arbor, MI, Open Humanities Press, 2012.

32 Francois Noudelmann, The Philosopher's Touch: Sartre, Nietzsche, and Barthes at the Piano, Trans. Brian J. Reilly, Columbia University Press, 2012.

${ }_{33}$ Noudelmann's argument would be interesting to apply to other philosophers. Emmanuel Lévinas - who has been mentioned several times in this text - wrote some of his most important work sitting a couple meters away from the piano where his son was practicing, or in the midst of conversation about music with his son, peers, and teachers. My current research examines these relations in more detail.

${ }^{34}$ Andrew Bowie, Music, Philosophy, and Modernity, Cambridge, Cambridge University Press, 2007, xiii, 14.
} 


\section{Music and Politics}

There are two common tendencies in discussions of music and politics. The first tendency is to consider only the relation between music and action related to the state. Areas of interest here might include the musical performances at Donald Trump's inauguration, political campaigns, military campaigns, and national anthems. ${ }^{35}$ These areas of investigation are of significant interest, but there has been a tendency to treat the musical practices listed above as 'political' and other music as separate from politics, holding on to the $19^{\text {th }}$ century idea of 'absolute' music. ${ }^{36}$ This view holds that private musical experiences are not political, a view that breaks down in the feminist argument that "the personal is political", ${ }^{37}$ an influential position in the post-1968 ethical turn.

The second tendency erases the separation of the personal and political by considering everything political since it involves power. In this view, programming one piece of music rather than another is political. Funding is political. Writing for particular instruments is political. Vocal production techniques are political. Extending the challenge of "the personal is to political" to the view that everything-is-political and finding that the most important things to investigate are the political codings of musical and other cultural actions has perhaps swung the pendulum in musicology so far from the previous untenable musicological separation of music and politics that becomes it's opposite and again flattens the possibilities for investigating music and politics. Unfortunately, too much scholarship that excellently criticizes power structures remains committed to the music-is-power position, leaving little hope of getting out of the paranoia of power. ${ }^{38}$ For too long power relations had been overlooked in musicology and other disciplines, and the influence of power - particularly the power of capital - on the world today cannot be ignored or underestimated. However, there is a need to go beyond overly simplified theorizations of music and politics. In short, while music involves (political) power, it cannot be reduced to power.

\footnotetext{
${ }^{35}$ For example, a high percentage of the articles in the journal Music and Politics (https:// quod.lib.umich.edu/m/mp) fit this form.

${ }^{36}$ For more on pure music, see Carl Dahlhaus, The Idea of Absolute Music, Chicago, University of Chicago Press, 1989.

${ }^{37}$ A term popularized in an essay by Carol Hanisch, "The Personal is Political", in: Shulamith Firestone and Anne Koedt (Eds.), Notes From the Second Year: Women's Liberation, New York, 1970.

38 For wider discussions about this topic, see Eve Kosofsky Sedgwick, Touching Feeling: Affect, Pedagogy, Performativity, Durham, Duke University Press, 2003; Suzanne G. Cusick, "Musicology, Torture, Repair", Radical Musicology, Vol. 3, 2008; and William Cheng, Just Vibrations: The Purpose of Sounding Good, University of Michigan Press, 2016.
} 
Much work about music and politics occurs in the wake of Adorno's claim that music unconsciously "contains social relations within its material and its structure" ${ }^{39}$ An extreme response to this argument is that all of political history lies latent within music, and history could be reconstructed with only music. Of course, this position too easily folds together music and (political) history. A more productive way forward in response to Adorno's insights, however, is to examine the ways in which ideas of the political subject are worked out in music, and how music is worked out through the political subject. ${ }^{40}$

In his book The Ethics of Authenticity, Charles Taylor explores how some late $20^{\text {th }}$ (and early $21^{\text {st }}$ ) century concerns such as relativism are the result of the development of the modern subject defined by self-determination. ${ }^{41}$ That music is merely personal and at the same time formative to the person is, according to Taylor, part of the same shift that led to the ethics of authenticity that dominate the political discourse of today. And while some of the major ideas were planted in the eighteenth century, it is in the shadow of the blossom of the latter half of the twentieth century that we find currently ourselves. Crudely put, we have moved from the pre-modern view of political life as natural order and art as imitation, to the Enlightenment view of reason guiding life and art as expression, to the post 1968 positions of identity politics and life as art.

Taylor examines how placing high value on self-determination and the individual seems to push against the customs of morality and leads to relativism, but paradoxically cannot. In Johann Gottfried Herder, Taylor finds a key articulation of the idea that "each of us has an original way of being human. Each person has his or her own 'measure' is his way of putting it. This idea has entered very deep into modern consciousness." 42 Relativist positions follow the logic of individual authenticity and claims that therefore "a liberal society must be neutral on questions of what constitutes a good life" ${ }^{43}$ Later, Michel Foucault links self-determination with the aesthetic ideals that developed along with the values of self-determination, allowing for "individual choice in self-formation, based, for example, on personal standards of aesthetic value, corresponding to what

\footnotetext{
39 Max Paddison, "Authenticity and Failure in Adorno's Aesthetics of Music", The Cambridge Companion to Adorno, Cambridge, Cambridge University Press, 2006, 211.

40 Several writers and musicologists take these ideas seriously. For example, Alex Ross's book The Rest is Noise aims to examine "the twentieth century heard through its music". Alex Ross, The Rest is Noise, New York, Picador, 2007, xvii.

${ }^{41}$ Charles Taylor, The Ethics of Authenticity, Cambridge, Mass., Harvard University Press, 1992.

42 Ibid., 28.

${ }^{43}$ Ibid., 17-18.
} 
Foucault calls an aesthetics of existence". ${ }^{44}$ Foucault asks: "couldn't everyone's life become a work of art?" 45

Instead of criticizing the notion of authenticity altogether for its shortcomings, Taylor claims that it is still quite useful, but needs correction from the ideas that lead to relativism. ${ }^{46}$ In short, he argues that "no one acquires the languages needed for self definition on their own", but that 'being ourselves' involves placing ourselves in dialogue with the world around us. ${ }^{47}$ Additionally, a larger group needs to agree that some decisions (say, a position against white supremacy) are more important than others (say, favourite ice cream flavour) ${ }^{48}$ Taylor claims, then, that "individualism as a moral principle or ideal must offer some view on how the individual should live with others" ${ }^{49}$ In other words, even if ethics and politics cannot become one, they also cannot be separated. And since music is bound up in these relationships, music is a participant in the dialogue.

Taylor claims that "with Herder, and the expressivist understanding of human life, the relation becomes very intimate. Artistic creation becomes the paradigm mode in which people can come to self-definition. The artist becomes in some way the paradigm case of the human being, as agent of original self-definition." 50 The core claim here is that artistic creation - and music in particular - becomes the model of a self-determining individual. Music, in other words, seemed to play a role in the development of the modern idea of a self-determining individual subject, and continues to play a role in the formation of modern subjectivity. In short, music is formative in the human relationships that make up ethical and political life.

Thus far, the direction of questioning has been from music to politics. In other words, the argument is that music participates in politics. The argument that all music is involved in politics in one way or another fits with many conventional theoretical positions. Changing the direction of the argument to question whether politics always involves music, however, is perhaps a bit more

\footnotetext{
44 Gary Gutting, op. cit., 143.

45 Michel Foucault, "On the Genealogy of Ethics: An Overview of Work in Progress", in: Paul Rainbow (Ed.), The Foucault Reader, New York, Pantheon Books, 1984, 350.

46 "I think that authenticity should be taken seriously as a moral ideal". Charles Taylor, op. cit., 22-23.

47 Ibid., 33

48 "Self-choice as an ideal makes sense only because some issues are more significant than others". Ibid., 39.

49 "Individualism as a moral principle or ideal must offer some view on how the individual should live with others", Ibid, 45.

${ }^{50}$ Ibid., 62
} 
fraught. Can one reasonably argue that music is part of, say, political economy? Music often takes a commodity form, so that provides a potential response. The sceptic might ask about music's role in residential zoning or foreign policy, and while there might be reasonable responses to each of these, a more fundamental response is music's role is shaping the people involved in politics.

In Nicholas Cook's Music: A Very Short Introduction, one of his central claims is that music "is less a 'something' than a way of knowing the world, a way of being ourselves". ${ }^{51}$ Throughout the book, he provides examples of how music both shapes and reflects identity and relationships to others. Music's ability to do this is wrapped up with cultural assumptions about what music is and what it does, which in turn are wrapped up in the development of the ideas of authenticity and selfhood. In musical experience, we negotiate and represent who we are, who we want to be, and how we relate to others. In short, music shapes us, and we shape the world (which includes, of course, music). Andrew Bowie puts this idea in more Heideggerian terms: "music is world-disclosive: the world itself can take on new aspects because of it". ${ }^{52}$ Seen this way, music and politics remain distinct but are never separate.

\section{Music ethics politics}

Returning back the examples this article began with, has this exploration of the interconnections of music, ethics, and politics brought us any further to consider how to respond to such events? I am under no presumptions that a few thousand words can solve such a complex and likely unsolvable problem. I hope, however, that this discussion has at least begun tracing possible helpful and problematic ways of theorizing music, ethics, and politics in a manner that can assist the development of responses. I begin with the negative conclusions of the argument.

First, music should not be thought of as separate from events like these. Most reports - at least in mainstream media - note that a concert was the site of the event, but do not look closer at the place of musical concerts in modern society. Too often assumptions that music is 'mere' entertainment pervades thought, and how music can bring together people - diverse in some ways, like minded in others - is ignored. The place of music is minimized by a reduction to entertainment or an elevation to something beyond ethics and politics.

Second, music's role in political and ethical discourses cannot be ignored. Assumptions that, for example, ethical philosophy begins with reason alone ignores that subjectivity of the person reasoning is shaped by many factors, and

51 Cook, Nicholas, Music: A Very Short Introduction, Oxford, Oxford University Press, 1998 , Forward.

52 Andrew Bowie, Music, Philosophy..., op. cit., 27. 
music is surely one of them. Additionally, the idea that music can and has opened new ways of thinking is too often absent in ethical and political discourse.

Instead, music enacts, reinforces, and provides new opportunities for politics and ethics. Music participates with ethics, politics, and many other things in the development of subjectivity both individually and as we strive to examine human subjectivity more generally. Echoing the title of Heidegger's essay discussed earlier, when considering music, ethics, and politics, we cannot think one without the other. Our interactions with music as listeners, creators, and scholars should continue to work out what this entwinement means.

\section{Works cited}

Adorno, Theodor W.: Problems of Moral Philosophy. Stanford, CA: Stanford University Press, 2001.

Bogost, Ian: Alien Phenomenology, or What it's Like to be a Thing. Ann Arbor, MI: Open Humanities Press, 2012.

Born, Georgina: "For a Relational Musicology: Music and Interdisciplinarity, Beyond the Practice Turn", Royal Musicological Association, Vol. 135, No. 2, 2010.

Bourg, Julian: From Revolution to Ethics: May 1968 and Contemporary French Thought. Montreal: McGill-Queen's University Press, 2007.

Bourriaud, Nicolas: Relational Aesthetics. Les presses du reel, 1998.

Bowie, Andrew: German Philosophy: A Very Short Introduction. Oxford: Oxford University Press, 2010.

---: Music, Philosophy, and Modemity. Cambridge: Cambridge University Press, 2007.

Cheng, William: Just Vibrations: The Purpose of Sounding Good. University of Michigan Press, 2016

Cook, Nicholas: "Anatomy of the Encounter: Intercultural Analysis as Relational Musicology", in: Critical Musicological Reflections: Essays in Honour of Derek B. Scott. Ed. by Stan Hawkins. Farnham: Ashgate, 2012.

---: Music: A Very Short Introduction. Oxford: Oxford University Press, 1998.

Critchley, Simon: "Introduction". The Cambridge Companion to Levinas. Ed. by R. Bernasconi and S. Critchley. Cambridge: Cambridge University Press, 2002.

Cusick, Suzanne G.: "Musicology, Torture, Repair", Radical Musicology, Vol. 3, 2008.

Dahlhaus, Carl: The Idea of Absolute Music. Chicago: University of Chicago Press, 1989.

Foucault, Michel: "On the Genealogy of Ethics: An Overview of Work in Progress", in: The Foucault Reader. Ed. Paul Rainbow. New York: Pantheon Books, 1984.

Gutting, Gary: Thinking the Impossible: French Philosophy Since 1960. Oxford: Oxford University Press, 2011.

Hanisch, Carol: "The Personal is Political", in: Notes From the Second Year: Women's Liberation. Ed. by Shulamith Firestone and Anne Koedt. New York, 1970.

Heidegger, Martin: Being and Time: A Translation of Sein Und Zeit. New York: SUNY, 1996. 
Meillassoux, Quentin: After Finitude: An Essay on the Necessity of Contingency. London: Continuum, 2009.

Heidegger, Martin: "Building Dwelling Thinking", in: Poetry, Language, Thought. New York: Harper Colophon Books, 1971.

Hoad, T.F.: The Concise Oxford Dictionary of English Etymology. Oxford: Oxford University Press, 1996.

Idhe, Don: Listening and Voice: Phenomenologies of Sound. $2^{\text {nd }}$ Edition. Albany: SUNY, 2007.

Lévinas, Emmanuel: Totality and Infinity. Pittsburgh, Pennsylvania: Duquesne University Press, 1969.

McVeigh, Tracy and Emma Graham-Harrison: "Parisians throw open doors in wake of attacks, but Muslims fear repercussions", The Guardian, 14 November 2015.

Merleau-Ponty, Maurice: "The Intertwining - the Chiasm", in: The Continental Aesthetics Reader. Ed. by Clive Cazeaux. New York: Routledge, 2000.

Noudelmann, Francois: The Philosopher's Touch: Sartre, Nietzsche, and Barthes At the Piano. Transl. by Brian J. Reilly. Columbia University Press, 2012.

Paddison, Max: "Authenticity and Failure in Adorno's Aesthetics of Music", The Cambridge Companion to Adorno. Cambridge: Cambridge University Press, 2006.

Ross, Alex: The Rest is Noise. New York: Picador, 2007.

Sedgwick, Eve Kosofsky: Touching Feeling: Affect, Pedagogy, Performativity. Durham: Duke University Press, 2003.

Taylor, Charles: The Ethics of Authenticity. Cambridge, Mass.: Harvard University Press, 1992.

Tharoor, Ishaan: "Are You a Jihadist? France's Checklist Includes Questions About Diet, Wardrobe and Not Listening to Music", Washington Post, 30 January 2015.

Warren, Jeff R.: Music and Ethical Responsibility. Cambridge: Cambridge University Press, 2014.

\section{Summary}

In the twenty-teens, music has been wrapped up in politics and ethics in several prominent events, including violent attacks at the Bataclan theatre in Paris and the Pulse Nightclub in Orlando, the profiling of musical listening habits in the French governments "stop jihadism" campaign, and the musical lineup of Donald Trump's presidential inauguration. Significant scholarship exists on music and politics, and interest in music and ethical philosophy is growing. More work, however, is needed in theorizing the connections between music, ethics, and politics. In 1951, Heidegger's essay "Building Dwelling Thinking" lists the words in the title without punctuation in an attempt to show how these three terms are intertwined even though they are often considered separate. While these words and concepts are not interchangeable, each relies upon or invokes the other. My title structurally mirrors Heidegger's, and my aim here is to elucidate how music is intertwined with ethics and politics. In earlier publications I argued that musical experience creates encounters with others, and that these encounters lead to ethical responsibilities. 
Here, I extend this argument to politics, drawing upon arguments from phenomenology, relational musicology, ethical and political philosophy. Relations between music, ethics, and politics cannot be completely enumerated, but include: music disclosing political possibilities, and music performing ethical ideas about self and other that influences politics. My hope is that considering the intertwinement of music, ethics, and politics might provide us - as citizens and those working with music - ith ways of responding to the events that surround us. 